\title{
Effectiveness of a Consumer Education Programme for Higher Secondary School Students.
}

\author{
Sasikumar.P ${ }^{1}$, Dr.P. Usha ${ }^{2}$ \\ ${ }^{I}$ (Research Fellow, Department of Education, University of Calicut, India) \\ ${ }^{2}$ (Associate Professor, Department of Education, University of Calicut, India)
}

\begin{abstract}
All education programs aims at creating awareness, attitude, and skill among the intended group. The study focuses on the development of a Consumer Education Programme, which aims to create awareness on consumer issues. The sample constituted a representative group of XI students of selected school of Kozhikode District. Mean Difference analysis is used to test the effectiveness of the developed consumer educationprogramme. Analysis of pretest and posttest scores reveals that there is significant difference in the mean scores of the pretest and posttest on consumer awareness of the selected sample. The findings show that the developed programme is effective. This type of programme will promote the development of similar awareness programs since the exploitation of consumers has been always at a high rate.
\end{abstract}

Key words: Consumer Awareness, Consumer Education,Higher Secondary school students.

\section{Introduction}

According to the basic theories of economics, for the maximization of satisfaction from the utilization of goods and services, everyone should allocate theiravailable income at the best among various needs. To this, the knowledge about the evolving market conditions of the society in which one lives is inevitable. There is a common saying that in the market"the Consumer is the King". However,it is only figurative. Even though the world has technologically advanced so much, especially Indians have less knowledge about the important consumer affairs. To make the saying true, one should know what factors that make a person a good consumer. such factors are the awareness about who is a consumer, what are the rights and responsibilities of a consumer, what laws and judicial systems are there to protect the consumers, how, when and where one can complain against various consumer exploitations, what things should be considered while doing purchase of goods and services etc. From higher secondary education stage onwards one becomes more active in buying goods and services due to various factors such as peer influences, advertisements, age and so on. They are more vulnerable to the moment-to-moment changes of the world. While analyzing the curriculum of Indian education system at any stage, it is very rare to see an elaborated and effective consumer education programme for students. What makes one a "king" is nothing but his knowledge. Here the study attempts to make an analysis about the effectiveness of a consumer education programme for higher secondary school students.

\section{Meaning and importance of consumer awareness}

The knowledge about allocation of available income among various needs in the most efficient way, ordering of various needs according to their importance, selection of the most suitable goods and services, knowing and facing the challenges while buying goods and services, the ways of ensuring legal protection when there arise problems to consumers etc., are generally considered as the features of consumer awareness.

Consumer awareness, which refers to a buyer's knowledge of a particular product or company, allows a buyer to get the most from what he buys. Consumers know more about their choices when they have product information and benefit from knowing their rights, hearing about alerts and warnings and finding about safety issues. It describes the awareness of a potential or current buyer about a particular product or company. It can be as simple as a shopper remembering a television commercial or as specific as a customer delving in to the manufacturing origins of a specific product. (Sahil-2013).It is the understanding by an individual of their rights as a consumer concerning available products and services being marketed and sold. (Kennedy, 2012).It has been observed very often that a consumer does not get right goods and services. He is charged a very high price for adulterated or low quality goods are sold to him. Therefore, it is necessary to make him aware. (Hakimuddin, 2012).Consumer awareness is making the consumer aware of His/hers rights. Consumer awareness is a marketing term. It means that consumers note or are aware of products or services, its characteristics and the other marketing P's (place to buy, price, and promotion). (Shashank, 2008).

Therefor it is obvious that consumer awareness means a state in which the consumers become informed about his rights and responsibilities while buying and using goods and services. Usually, there will be an 
important question about the rights and responsibilities of a consumer since it has that much importance in consumer education. So here needs a very short description about the rights and duties of a consumer.

The United Nations Organization's Guidelines and the Consumer Protection Act-1986 of India undoubtedly states about the six rights of a consumers. They are:

1. Right to safety

2. Right to information

3. Right to choice

4. Right to be heard

5. Right to redress

6. Right to consumer education.

While analyzing the above-mentioned six rights of consumers, it is very important to note that there are great efforts at the global and national level to protect the interest of the consumers. A consumerhas (1) the right to be protected against the marketing of goods, which are hazardous to life and property, (2) the right to be given the facts needed to make an informed choice or decision about the product. (3) He has the right to be assumed, wherever possible, access to a variety of goods at competitive prices, (4) the right to be allowed to voice their opinions and grievances at appropriate form and (5) the right to get remedies to the problems and disputes. The right to consumer education (6), envisaged in the UN'S Guidelines and Consumer Protection Act of India is a right indication of the pathetic situation of consumers and stresses to make enough consumer education programmes to improve their welfare.

In addition, consumer awareness also consists of the duties and responsibilities that should be strictly followed by the consumers. The responsibilities of a consumer can be classified in to the following heads.

1. Responsibility towards the society and family,

2. Responsibility towards the government,

3. Self-responsibility and

4. Responsibility towards the environment.

A discussion about these important duties of a consumer will lead us to the conclusion that a strict acceptance of these duties can solve almost all consumer problems in a well manner. But, the question, how that self -acceptance of the duties and theunderstanding of rights by the consumers are possible, leads to the need of a new branch of study, which in short is known as "Consumer Education."

\section{Need And Significance Of The Study}

Since a human being is a consumer from the conception onwards, it is very important to impart at least the basic education about the important consumer affairs to all people.It is a well-known fact that consumer confidence is built on knowledge, skills and attitudes. These are very essential to maximize the satisfaction of the individuals and to create a harmless and favourable business environment. Informed consumer knows his rights, the functioning of the markets, and what they are going to buy. A skilled consumer will be able to negotiate where it is necessary, and to regulate his budget. A good consumer will be ready to protect the wellbeing of others also.

A planned education programme at the central or state level through education is the meaningful way to inculcate consumer awareness, skills and attitudes among the people. Hence, the prevailing situation requires an acceptable solution;"Consumer Education” is the best means to achieve it.

\section{Consumer Education}

\section{Definition Of Key Terms}

The US Department of Education (1994) defined Consumer Education as"the process of gaining the knowledge and skills needed in managing consumer resources and taking actions to influence the factors which affect consumer decisions".

\section{Consumer Education Programme}

For the present study, Consumer Education Programme denotes a systematic and conceptually developed programme to impart knowledge, awareness and skills to the students regarding consumer behaviour.

\section{Variabels Of The Study}

The present study requires the use of the following independent and dependent variables.

\section{Independentvariable}

The independent variable of the study is the transaction of a Consumer Education programme. 


\section{Dependent Variable}

The dependent variable is the development of good consumer awareness, which includes nurturing of the components such as consumer awareness about the rights and responsibilities of a consumer, healthy attitudes and acquisition of basic skills.

\section{Objectives Of The Study}

The major objectives of the study are the following.

1. To develop a Consumer Education Programme for the higher secondary schools students to create consumer awareness.

2. To test the effectiveness of the developed Consumer Education Programme.

\section{Hypotheses Of The Study}

The hypotheses of the present study are:

1. There is no significant difference in the pretest scores of consumer awareness of boys and girls.

1. There will be significant difference in the pretest and post-test scores of consumer awareness for the total sample.

2. There will be significant difference in the pretest and posttest scores of consumer awareness for boys and girls.

\section{Procedure}

1. Preparation of an awareness test on Consumer Education.

2. Testing the awareness of higher secondary school students before the implementation of the programme (pretest).

3. Development of a Consumer Education programme.

4. Transaction of the Consumer Education Programme.

5. Testing the awareness on Consumer Education after transaction of the programme (posttest).

6. Testing the effectiveness of the developed Consumer Education Programme.

Design

VIII. Methodology

The study is a single group pre-test - post-test experimental design in to find out the efficiency of the developed consumer education programme.

\section{Sample of the study}

The sample selected for this study comprises of 50 higher secondary school students from a selected school of Kozhikode district of Kerala. It includes 32 girl students and 18 boys. The sample is selected through convenient sampling method.

\section{Tools and statistical Techniques of the study}

A standardized test comprising 46 items exclusively based on consumer awareness is prepared as the pretest and posttest for this study. The items are based on the content of the leaning material prepared for consumer education.

Mean difference analysis (t-test) wasused in the study to find out the effectiveness of the Consumer Education Programme.

Since one of the main objectives of the study is to develop a consumer education programme for higher secondary school students, an instructional material is prepared based on expert advices and wide review of related literature.Details of the developed Instructional Material on Consumer Education are given below:

1. The Instructional material is developed in Malayalam language since the study gives preference to higher secondary students of Kerala.

2. The developed includes nine simple chapters and the main contents are;

a) Meaning, scope, importance and definitions of Consumer and Consumer Education

b) Growth of Consumer Education in India and abroad.

c) UN'S guidelines on consumer protection

d) An analysis of consumer behavior

e) Consumer Protection Laws in India.

f) Factorsdeveloping a good consumer behavior.

g) Indian Judicial system for consumer protection.

h) Methods of filing consumer complaints.

The chapters of the material include important concepts of Consumer Education such as 
1. Symbols, terms and theories related with consumer education

2. Follow up activities after each chapter

3. Names of important consumer protection agencies and judicial system In India.

4. Things to be noted while filing consumer complaints and

5. Model forms for filing consumer complaints.

Twenty lesson plans based on the content of the material were prepared and taught the students within the prescribed time. Discussions, debates, analysis of different consumer goods, seminars, sharing of experiences were conducted as part of the experiment.

\section{Analysis And Interpretations}

A brief discussion about the analysis of study is given below.

\section{The Mean Difference Analysis}

TABLE.1

Results of the Test of Significance of the Difference between the Mean consumer awareness pretest scores for the selected sample based on gender

\begin{tabular}{|c|c|c|c|c|c|c|}
\hline variable & Gender & $\mathrm{N}$ & Mean & SD & $\mathrm{t}$ & LS \\
\hline \multirow{2}{*}{$\begin{array}{l}\text { Pretest scores on } \\
\text { Consumer Awareness }\end{array}$} & Boys & 18 & 16.89 & 3.98 & \multirow{2}{*}{0.547} & \multirow{2}{*}{ NS } \\
\hline & Girls & 32 & 17.6 & 4.3 & & \\
\hline
\end{tabular}

The Mean Difference analysis of pretest scores of the selected sample reveals that there is no significant difference in the mean scores of consumer awareness for the selected sample based on gender.On consumer issues, male and female students have almost equal knowledge.

TABLE.2

Results of the test of significance of the difference between the Meanconsumer awarenesspretest and posttestscores for thetotal sample

\begin{tabular}{|l|l|c|c|c|c|c|}
\hline Variable & & $\mathrm{N}$ & Mean & SD & t & \\
\hline \multirow{3}{*}{$\begin{array}{c}\text { Consumer awareness } \\
\text { (Total sample) }\end{array}$} & Pretest & 50 & 17.32 & 4.15 & \multirow{2}{*}{13.83} \\
\cline { 2 - 5 } & posttest & 50 & 30.28 & 5.16 & & \multirow{2}{*}{0.01} \\
\hline
\end{tabular}

The Mean Difference analysis of the pretest and posttest scores on consumer awareness for the total sample reveals that there is significant difference in the mean scores of consumer awareness for the total sample. It shows that the developed Consumer Education Programme is effective in transacting consumer awareness.

TABLE.3

Results of the Test of Significance of the difference between the Mean Scores of on consumer awareness for the selected sample based on gender

\begin{tabular}{|c|c|c|c|c|c|c|c|}
\hline variable & Gender & & $\mathrm{N}$ & Mean & $\mathrm{SD}$ & $\mathrm{t}$ & LS \\
\hline \multirow{4}{*}{$\begin{array}{l}\text { consumer } \\
\text { awareness }\end{array}$} & \multirow[t]{2}{*}{ Boys } & Pretest & 18 & 16.89 & 3.98 & \multirow[t]{2}{*}{8.72} & \multirow[t]{2}{*}{0.01} \\
\hline & & posttest & 18 & 30.61 & 5.22 & & \\
\hline & \multirow[t]{2}{*}{ Girls } & pretest & 32 & 17.56 & 4.3 & \multirow[t]{2}{*}{10.51} & \multirow[t]{2}{*}{0.01} \\
\hline & & posttest & 32 & 30.09 & 5.21 & & \\
\hline
\end{tabular}

The Mean Difference analysis of the pretest and posttest scores on consumer awareness for male and female students reveals that there exists significant difference in the mean scores on consumer awareness for boys and girls. This result also reveals that the developed Consumer Education Programme is effective.

The results of the analysis is a clear indication that there will be fruitful changes in the consumers regarding the ongoing issues related to the buying and selling of goods and services, if they are assisted with awareness programs. The results also show that well-developed consumer awareness programs will create advantagesto all 
gender and will boost their knowledge in selecting goods and services, facing market challenges, seeking redresses on disputes etc.

\section{Conclusion}

The main objective ofthe present study was to analyze the effectiveness of the developed consumer education programme. Since the consumer awareness programs of the government and different companies are limited to some particular area or they are time related, the study is intended to develop a comprehensive consumer education programme that includes the maximum information and to test its effectiveness. Since the number of consumer exploitation cases are steadily increasing, at least some kind of awakened actions regarding the rights and responsibilities of consumers should be inculcated in the coming generations. This is an important educational implication of the study. Proving that it is possible through developed consumer education programs, the study alsopromotes further studies in this area.

\section{References}

[1]. Block, E.C. (1976).Essentials of Consumer Behaviour: Illinois, The Dryden Press.

[2]. Hellman, G (1985).Promoting Consumer Education in Schools: Penang.

[3]. School curriculum development Committee. (1987).Curriculum Development for Consumer Education: England and Wales.

[4]. Fazal, A \&Sing.B. (1991).Consumer education: A Resource Hand Book: International Organization for Consumer Unions. Malaysia

[5]. Childer.T\&Rao.A.R. (1992).The Influence of familial and peer based reference groups on consumer decisions. Journal of Consumer Research, Inc.vol.19.

[6]. Kostecky, M.M. (1995). The consumer in a socialist economy. European Journal of Marketing, vol.19.

[7]. Sing .G. (1996). The law of consumer protection in India: Justice within reach: New Delhi, Deep\&Deep Publications.

[8]. Sing.S.S \&Chadha.S (1997).Consumer protection in India: Some reflections. New Delhi, IIPA.

[9]. Nair.R.S. (2002).Consumer behaviour in Indian perspective. Mumbai, Himalaya Publishers.

[10]. Kumar. R.S. (2003).Conceptual issues in consumer behaviour; The Indian context. New Delhi, Pearson Education, Singapore (p) Ltd.

[11]. Jing Jian Xiao et.al. (2004).A consumer education programme based on the Trans theoretical model of change. International Journal of Consumer Studies, 55-66, vol.28.

[12]. Carole. J.M\&Peters.S. (2004).Consumer education: Creating consumer awareness among adolescents in Botswana. International Journal for Consumer Studies, vol.28.

[13]. Banister.et.al. (2005). The classification of concepts in consumer education. Eastern Michigan University. Ypsilanti.

[14]. Fraj.E \& Eva.M. (2006).Ecological consumer behaviour: An empirical analysis. International Journal of Consumer Studies. Vol.31, Blackwell Publishing Ltd.

[15]. Girimaji.P. (2006). Misleading advertisement and consumers. New Delhi, IIPA

[16]. Chandra.R. (2006). Towards a new perspective on consumer education. Edutracks, 11-14, vol.5.No.12

[17]. Hoyer \&lnnis.M. (2007).Consumer behaviour, fourth edition. Boston, New York.

[18]. Majumdar.R. (2010).Consumer behaviour: Insights from Indian market. Haryana.

[19]. Bethon.P.et.al. (2011). Creative consumers: awareness, attitude and action. Journal of Consumer Marketing, vol.28, iss.7.

[20]. Hakimuddin, Consumer awareness: Importance of consumer awareness and rights of consumers, India study channel.com, Aug.2012.

[21]. Kennedy, Know your rights as a consumer, High Country Press/HCPress.com, May- 2012

[22]. M.Sahil, A research project report on consumer awareness and perception towards woolen shawls, www.slideshare.net,April-2013. 